\title{
CHEATING BEHAVIOR IN EFL CLASSROOM (A CASE STUDY AT ELEMENTARY SCHOOL IN SIDENRENG RAPPANG REGENCY)
}

\author{
Andi Asrifan ${ }^{1}$, Abd. Ghofur ${ }^{2}$, Nur Azizah ${ }^{3}$ \\ ${ }^{1}$ English Education Department, Faculty of Teacher and Training, Universitas Muhammadiyah Sidenreng \\ Rappang, South Sulawesi 91651, Indonesia \\ ${ }^{2}$ English Teaching and Learning Program, Tarbiyah Faculty, Institut Agama Islam Negeri Madura, Pamekasan \\ 69371, Indonesia \\ ${ }^{3}$ English Education Department, Faculty of Teacher and Training, Universitas Muhammadiyah Sidenreng \\ Rappang, South Sulawesi 91651, Indonesia
}

\section{A RTICLE INFO}

Keywords:

Cheating behavior

Teachers' strategy

Gender

Article History:

Received: 30/11/2020

Accepted: 30/11/2020

Available Online:

$30 / 11 / 2020$

\begin{abstract}
A B S T R A C T
Cheating is a common problem yet unresolved issue in the classroom. Some factors make the students cheat, and they do it continually. This article aims to find factors that influence student cheating behavior; the strategies used by the English teacher to overcome student cheating behavior; and the difference in student cheating towards gender. This research is a case study using a descriptive qualitative method. The subjects were UPT SDN 1 Rijang Panua, a sample of schools with 4-grade to 6-grade classes. The questionnaire and the interview were used to collect the data. Data analysis techniques were sequential-parts of the study by Starovoytova and Namango. The result shows that: 1) Three categories of factors that influence student cheating behavior namely a) the situational factor; b) the individual factor; and c) the teacher factor; 2) There are four strategies to overcome student cheating behavior in the EFL Classroom such as explaining the bad impact of cheating behavior, instill character education at an early age, give questions-answer or quiz exercises and give appreciation or praise; 3) there is no difference between cheating behavior based on gender.
\end{abstract}

2442-305X / (C) 2020 The Authors, this is open access article under the (CC-BY-NC) license (https://creativecommons.org/licenses/by-nc/4.0/), DOI: 10.19105/ojbs.v14i2.4009

\footnotetext{
$\overline{\text { * Corresponding Author: }}$

Email address: andiasrifan@gmail.com (A. Asrifan)
}

\section{A. Introduction}

Cheating is one of the educational phenomena that frequently appears to be part of the teaching and education process but receives no severe attention of the Indonesian discourse on education. Cheating can also be said as a tradition or an unperished habit. It is not a new phenomenon. ${ }^{1}$ The development of

\footnotetext{
${ }^{1}$ Suncana Kukolja Taradi, Milan Taradi, and Zoran Dogas, "Croatian Medical Students See Academic Dishonesty as An Acceptable Behaviour: A CrossSectional Multicampus Study," Journal of Medical Ethics 38, no. 6 (June 2012): 376-79, https://doi.org/10.1136/medethics-2011-100015.
} 
technology is a further reason. Technology gives students the laziness to study. In the end, they chose to cheat during the review because there was no preparation before and lack of confidence in their ability. They also wanted to use social media like Facebook, Twitter and Instagram at any time. The benefit to students is dishonest, including cheating, plagiarizing, stealing and faking something that relates to academia, obtaining answers before the test being implemented, seeing book at the time of examination, and other things. While Anderman and Murdock define the details in three tags: 1) Give, take or receive data, 2) Use prohibited materials or notes, and 3) Using a weakness, procedure, or process for academic adventure. ${ }^{2}$

Based on the phenomena, researchers want to know more about the habit of cheating, particularly in elementary schools, in their daily activities. In reality, however, further empirical factors are necessary for the variables that play a central role in the students' attitudes and behavior in language classes. Therefore, the present study examines the links between the exams of EFL students and their trickery habits to trick and their trickery conduct in a language class and will look more into the study of cheating behavior at the EFL classroom (Case study at UPT SDN 1 Rijang Panua). Three problems were tackled in this study. The first is the factors that influence students' cheating

2 Eric M. Anderman and Tamera B. Murdock, Psychology of Academic Cheating (Amsterdam: Elsevier, 2011), 124. behavior in the EFL Classroom. The second is how the strategies used English teachers to overcome students' cheating behavior in the EFL Classroom. The Third is the difference in student attitudes towards cheating behavior by gender.

\section{Character Education and Education Value}

Character education consists of two words, education and character. Education is defined as a conscious and planned effort to create someone who can be useful in the future, the character is psychological nature, morals or manners that distinguish one person from another. ${ }^{3}$ Therefore the character education is an effort that is carried out to develop good character education based on virtue-virtue of the core (cor virtues) that are objectively good for individuals and society. ${ }^{4}$

Character education has the same meaning as moral education and moral education, where the goals are to shape the child's personal character to be human and a good citizen. ${ }^{5}$

In universal, the variety of characters is formulated as the value of

3 John Dewey, Experience And Education (New York: Simon and Schuster, 2007), 97.

4 Saptono, Dimensi-Dimensi Pendidikan Karakter: Wawasan, Strategi, dan Langkah Praktis (Jakarta: Erlangga, 2011), 42.

${ }^{5}$ Zainuddin Syarif and Abdul Gaffar, "The Model of National Character Education in Darul Ulum Islamic Boarding School of Banyuanyar, Pamekasan Madura," in Proceedings of the International Conference on Islamic Education (ICIE 2018), vol. 261 (International Conference on Islamic Education (ICIE 2018), Bandung, Indonesia: Atlantis Press, 2018), 119-22, https://doi.org/10.2991/icie18.2018.22. 
living together based on several pillars: peace, respect, cooperation, freedom, happiness, honesty, humility, compassion, responsibility, simplicity, tolerance, and unity. $^{6}$

Character values are described in the following table.

Table 1.

Values Character and a Description of the Character

\begin{tabular}{|c|c|c|}
\hline No & Character & Value Description \\
\hline 1. & Peace & $\begin{array}{l}\text { Attitudes and behavior like } \\
\text { the absence of harmony } \\
\text { and free from conflict and } \\
\text { disorder and the like, will } \\
\text { be peace. }\end{array}$ \\
\hline 2. & Appreciate & $\begin{array}{l}\text { Appreciate yourself, } \\
\text { others, and the } \\
\text { environment. Be civilized, } \\
\text { polite, not abusive, not } \\
\text { insult others, and not judge } \\
\text { others before knowing him } \\
\text { better. }\end{array}$ \\
\hline 3. & Cooperation & $\begin{array}{l}\text { Helping each other to } \\
\text { achieve a purpose }\end{array}$ \\
\hline \multirow[t]{2}{*}{4.} & Freedom & $\begin{array}{l}\text { The absence of coercion/ } \\
\text { pressure accidentally }\end{array}$ \\
\hline & & $\begin{array}{l}\text { urges someone to do } \\
\text { something against the will } \\
\text { of yourself. }\end{array}$ \\
\hline 5. & Happiness & $\begin{array}{l}\text { A state where the present } \\
\text { pleasure, peace, and } \\
\text { satisfaction to ascertain } \\
\text { what has been achieved. }\end{array}$ \\
\hline 6. & Honesty & $\begin{array}{l}\text { Uphold the truth, sincere } \\
\text { and straight days, do not } \\
\text { like to lie, steal, and } \\
\text { defame, never meant to } \\
\text { plunge the other. }\end{array}$ \\
\hline 7. & Humility & $\begin{array}{l}\text { Acknowledge the role and } \\
\text { services of the other and } \\
\text { self-effacing. }\end{array}$ \\
\hline
\end{tabular}

6 Muchlas Samani and Hariyanto, Pendidikan Karakter Konsep dan Model (Bandung: PT Remaja Rosdakarya, 2013), 43.

\begin{tabular}{lll}
\hline 8. Affection & $\begin{array}{l}\text { Has and show feelings of } \\
\text { full compassion, love, and } \\
\text { be full of tenderness. }\end{array}$ \\
\hline 9. & Responsible & $\begin{array}{l}\text { Performing the task } \\
\text { wholeheartedly, working } \\
\text { with a high work ethic, } \\
\text { striving to achieve the best } \\
\text { performance, capable of } \\
\text { self-control and disciplined } \\
\text { self. }\end{array}$ \\
\hline 10. Simplicity & $\begin{array}{l}\text { A state about how to apply } \\
\text { simple, not ostentatious. } \\
\text { Opulence, not like-minded } \\
\text { inquisitive, } \\
\text { complicated. }\end{array}$ \\
\hline 11. Tolerance & $\begin{array}{l}\text { Accept openly other the } \\
\text { level of maturity and } \\
\text { background different. }\end{array}$ \\
\hline 12. Unity & $\begin{array}{l}\text { Establish a sense of } \\
\text { togetherness and mutual } \\
\text { complement each other } \\
\text { and establish a sense of } \\
\text { humanity and mutual } \\
\text { tolerance. }\end{array}$ \\
\hline
\end{tabular}

\section{Attitude}

\section{a. Understanding Attitude}

Attitude is defined differently by experts. An attitude is a form of a person's statement against things that he encountered as objects, people or phenomena. Attitude needs stimulus to produce a response. Attitude is a feeling of favor or partiality (favorable) and a feeling of no support (unfavorable) on an object. $^{7}$ The term attitude or attitude at first is used to indicate the mental status of the individual. Attitudes can guide the

\footnotetext{
7 Josep-Maria Cots, "Teaching 'with an Attitude': Critical Discourse Analysis in EFL Teaching," ELT Journal 60, no. 4 (2006): 336-45, https://doi.org/10.1093/elt/ccl024.

${ }^{7}$ venes in Tanya K. Altmann, "Attitude: A Concept Analysis," Nursing Forum 43, no. 3 (2008): 144-50, https://doi.org/10.1111/j.1744-6198.2008.00106.x.
} 
individual's behavior so that the individual will act following the attitude expressed. The individual's consciousness to determine the real behavior and the behavior that may occur is the attitude. ${ }^{8}$

Antony defines attitude as an expression of values or view of life that is owned by someone that attitudes can be formed, resulting in the behaviors $\mathrm{pr}$ actions desired ${ }^{9}$. Attitude is a readiness to respond that is positive or negative toward the object or situation consistently. Different opinions from the previous opinions that attitude is the internal ability of that role once in taking action, the more so if it opens a range of possibilities to act. Nations of the attitudes above can conclude that the attitude is of value owned by a person in response to the phenomena.

\section{b. Components of Attitude}

There are components of attitudes into three components. The first is the cognitive component that shows behavior that exists in a person associated with the object of the attitude it faces. The second is the affective component that concerns the emotional problem subjective someone against an object attitude. The emotional reaction of the affective component is much influenced by the confidence entrusted for a specific object. And the last is the conative component, a component that shows behavior in a

\footnotetext{
${ }^{8}$ Samuel Blankson, Attitude (North Carolina: Lulu.com, 2005), 1.

9 Anthony R. Pratkanis, Steven J. Breckler, and Anthony G. Greenwald, Attitude Structure and Function (East Sussex: Psychology Press, 2014), 237.
}

person associated with the object of the attitude that it faces. Furthermore, Haddock and Mario divide the attitude into three types, affective, cognitive, and behavioral. $^{10}$

\section{c. The Factor Forming the Attitude}

The factor forming the attitude of the individual are presented as follow. The first is a personal experience. Personal experiences leave a strong impression and can be both the basis of the formation of attitudes. The attitude is more easily formed when personal experience occurs in situations involving emotional factors.

The second is culture. Culture imparts the influence of the attitude toward the various problems. Culture has colored the attitude of the members of the society because of the cultural pattern of individuals who become members of community groups.

The third is other considered important. In general, individuals tend to have a conformist attitude or direction with people's attitude thinks is important. This trend is motivated by the desire to affiliate and avoid conflict with people considered important.

The fourth is the mass media. As a mess of communication, mass media like television, radio, newspaper, magazines, and others greatly influence opinion and belief formation. In the delivery of information, the mass media provide messages that contain suggestions that can steer someone's opinion. If strong

\footnotetext{
10 Greg Maio and Geoffrey Haddock, The Psychology of Attitudes and Attitude Change (California: SAGE Publications, 2009), 115-17.
} 
enough, book suggestions will teach the basic effectiveness in assessing a case to form the direction of certain attitudes.

The fifth is educational institutions and religious institutions. Understanding good and bad, something that should and should not be done, is obtained from education and religion. The concept of moral and religious teachings determine those belief systems, then these concepts play a role in determining individual attitudes to a thing.

And the last is emotional. A form of attitude statements based on emotions serves as channeling frustration or diversion of the ego's defense mechanism.

\section{Cheating}

\section{a. What Cheating is}

Cheating is derived from the word cheating which breaks, copes, torments, which means citing the writings, and so forth as the original, plagiarized. ${ }^{11}$ While Anderman and Murdock stated that academic fraud behavior is the use of al completeness of the material or assistance not allowed to be used in academic tasks and activities that interfere with the assessment process. ${ }^{12}$

Cheating is the act of using ways that are not legitimate for legitimate and respectable purposes to get the academic

11 James Athanasou and Olabisi Olasehinde, "Male and Female Differences in Self-Report Cheating," Practical Assessment, Research, and Evaluation 8, no. 1 (2019): 1-12, https://doi.org/10.7275/b4te$5 z 13$.

12 Anderman and Murdock, Psychology of Academic Cheating, 162. success to avoid academic failure. ${ }^{13}$ Meanwhile, cheating is a fraudulent act that is deliberately done when someone is looking for and requires recognizing the learning outcomes of others, although in an unauthorized manner.

\section{b. Factors that Cause Cheating}

Some factors emerge why the students cheat. One of the reasons that push individuals to cheat is to satisfy the expectations of parents. Parents in raising or educating their children are influenced by the parents' desire or ambition without looking at the ability of their child. Parents intend to provide the best for their children, but they ignore the ability of the child. Expecting too much on the child will hinder the child from demonstrating achievement by its potential. Children is aware of the expectations of her parents. Therefore, attitudes that are too demanding may cause chidren to feel afraid of losing their parents' affection. This gives rise to a sense of low selfesteem, behavior disorders, lack of motivation to learn, and tension are anxiety in the child.

Several factors that cause students to cheat on an exam are described below.

1) "Study results" in the form of numbers and grades obtained by students in the test are formative or summative.

2) Moral education, both at home and at school, is less applied in the lives of students.

\footnotetext{
${ }^{13}$ Athanasou and Olasehinde, "Male and Female Differences in Self-Report Cheating," November 23, 2019, 1.
} 
3) A lazy attitude that is embedded in students so far in mastering the subjects and less responsible.

4) Children teens often cheat than in Elementary School because adolescents need to have many friends and are popular.

5) Less understand the meaning of education.

\section{c. Cheating Behavior}

Cheating behavior will result in the action or character is not confident, undisciplined, irresponsible, does not want to read book lessons but diligently make notes of small to material cheating, justifies all sorts of ways, and eventually become the corruptor. Thus it appears that the cheating behavior is not directly educating students to be a corruptor.

Cheating behavior is not new in the academic problem. Cheating behavior is a kind of student behavior. ${ }^{14}$ In general, it can be understood that cheating involves an act of deceptions, deceptions, or betrayal that often unfairly advantages that cheater over the ability of other people. However, a cursory review of the literature suggests no universally embraced definition of academic cheating. For example, some researchers have defined affair indirectly and vaguely, such as "a violation of an institution's policy on honesty," while others seem to have left the meaning of cheating up to students'

\footnotetext{
14 Judy Sheard, Selby Markham, and Martin Dick, "Investigating Differences in Cheating Behaviours of IT Undergraduate and Graduate Students: The Maturity and Motivation Factors," Higher Education Research \& Development 22 (2003): 91-108, https://doi.org/10.1080/0729436032000056526.
}

interpretation by asking them directly how often they dishonest on their work or use cheat notes when they take tests. More typically, researchers have avoided such ambiguity or subjectivity, respectively, by asking students how often they have engaged in a specific set of behaviors, such as copying from a neighbor during an examination or copying material without acknowledging the source. ${ }^{15}$ This latter approach is sometimes combined with the corresponding set of questions that asks students if they consider the behavior cheating or rate how serious.

Cheating in exams is a serious problem that negatively affects education, social and psychological effects. Educationally, cheating is contrary to higher education's spirit and purpose, especially in shaping, developing, and promoting moral values and attitudes. Moreover, it violates institutional regulations, and it is an indicator of a school's inability to provide an educational process that offers equal opportunities for all students to learn. Socially, cheating is unacceptable behavior to get something incorrect and should be avoided. Cheating affects students who cheated and other students as it forces them to live in an unfair system so that students begin not to trust their ability of themself. Most importantly, cheating behavior may carry over after graduation, and it will be very difficult to break the habit. Psychologically,

\footnotetext{
15 Leo Andrew B. Diego, "Friends with Benefits: Causes and Effects of Learners' Cheating Practices During Examination," IAFOR Journal of Education 5, no. 2 (2017): $121-38$, https://doi.org/10.22492/ije.5.2.06.
} 
cheating may cause instability in a student's values, potentially resulting in serious psychological problems such as feeling guilty and ashamed.

\section{d. Forms of Cheating}

Hetherington and Feldman grouped cheating behavior into four types. ${ }^{16}$ The first is social active such as see the answers to other friends when the exam takes place or asking for answers from other friends when the exam is being held.

The second is IndividualisticOpportunistic. Such as using a HP (mobile phone) or the other electronic applience that is prohibited when the exam is veing held; prepare notes used at the time of the exam will take place; and view and copy that part or all of work of the other at the time of the test.

The third is individually planned. These acts include replacing the answers when the teacher out of the classroom. Opening the textbooks when the exam is being held and utilizing the teacher's negligence/weakness when cheating.

The last is social passive. The acts like allowing others to see the answers when the exam is being held, letting other copies work, and giving answers to the test to a friend when the exam is being held.

\section{e. Cheating in Terms of the Moral Aspects}

One important difference between humans and animals is because human beings are rational. Sense of decency is not other than about good and bad feelings associated with certain norms that apply. Someone will feel satisfied when they have been doing good things; otherwise, someone will feel regret when it is not doing well. Argued that moral behavior depends on the ability of a number of factors, namely: (a) Think about ethical dilemmas, (b) Consider the long term consequences of each action, and (c) to feel what is perceived by others. And it can be concluded that humans have instincts and the ability to distinguish the good deeds and bad, right and wrong, and therefore humans have equal potential between doing good by doing evil. Through cognitive thinking, humans can do moral reasoning, but it proves that ethical reasons have a low correlation with moral behavior.

\section{Gender}

\section{a. Teen Boys and Girls}

Gender refers to the characteristic of people as male and female. Gender identity involves the meaning of gender itself, including the knowledge of understanding and acceptance as men and women. ${ }^{17}$

The role of gender is a set of hope that set out how a female or male should

\footnotetext{
${ }^{16}$ E. Mavis Hetherington and Solomon E. Feldman, "College Cheating as a Function of Subject and Situational Variables," Journal of Educational Psychology 55, no. 4 (1964): 212-18, https://doi.org/10.1037/h0045337.
}

17 Gun Lidestav and Annika Egan Sjölander,
"Gender and Forestry: A Critical Discourse Analysis
of Forestry Professions in Sweden," Scandinavian
Journal of Forest Research 22, no. 4 (2007): 351-
62, https://doi.org/10.1080/02827580701504928. 
think, act, and feel. There are various ways to see their development. Some views emphasize biological factors in women's behavior, and the other emphasize the social aspects or cognitive. However, even experts with the environment's orientation the powerful recognize that girls and boys are treated differently because of differences in the physical and their different roles in reproduction. ${ }^{18}$

In addition to biological and social factors, cognitive factors contribute to developing the child's gender. While this is a cognitive theory most widely accepted of gender, gender stereotypes emerged when children gradually develop schemas of gender, what is appropriate and inappropriate based gender in their culture. The scheme is the structure of the cognitive network of associations making the individual's perception. Gender scheme sets the world in terms of women and men. Children are internally motivated to perceive the world and act according to the scheme they develop little by the children choose the appropriate gender and gender inappropriate in their culture and develop a scheme of gender that shapes how they see the world what they remember. Children are motivated to act in way that is following the gender of such scheme.

18 M. Lazar, Feminist Critical Discourse Analysis: Gender, Power, and ldeology in Discourse (London: Palgrave Macmillan, 2005), https://doi.org/10.1057/9780230599901.

\section{b. The Classification of Gender is} Viewed from the Gender Roles

The classification of gender roles involves the evaluation of boys and girls in terms of group personality traits. In the past, a male child is well taken care of should be independent, aggressive, and powerful. A woman who is well taken care of should not have nurturing nature and is not interested in power. Simultaneously, overall, the masculine characteristic is considered healthy and good by society, while the attributes of feminism are not exciting.

\section{c. The Interaction of Teacher and Students}

The bias between the male and female present in the classroom. Teachers interact more with boys than with girls at all levels of education. There are several factors to consider.

1) Obedient, follow the rules, and be neat and regularly assessed and reinforced in many classes. This is a behavior that is usually associated with girls and boys.

2) The majority of teachers are women, especially in elementary school. It can make boys more challenging to identify the teacher and imitate their teacher's behavior than girls.

3) Boys are more likely to be identified to have learning problems compared to girls.

4) Boys are more likely to be criticized than girls.

5) Personal schools tend to give stereotypes problematic in boys. 
Here are factors that becomes proof that class is common among girls.

1) In a special class, girls are more obedient, and boys are rougher. Boys demand more attention. Girls tend to wait for their turn. Educators worry that girls' tendency to be silent and obedient has the impact that the firmness is reduced.

2) In many classrooms, teachers spend more time and attention on boys while girls work and interact with themselves. Most of the teachers don't intentionally favor boys by spending more time with them, but somehow the class ends with the type of profile gender.

3) The boys get instructions a lot more help than girls when they are having trouble with the questions. The teacher often gives boys more time to answer questions, hints at the correct answer, and try to give the wrong answer.

4) Girls and boys entered the class with self-esteem levels the same, but after the secondary school level, women's self-esteem is significantly lower than in boys.

5) Although girls in the identification of the program for gifted more than boys, more boys in the program are more talented in high school.

\section{d. The Difference in the Attitude of Men} and Women Against the Behavior of Cheating in the Exam

Agger and Meece prove that women have a higher level in the achievers' orientation in academic performance. ${ }^{19}$

${ }^{19}$ Charlotte Agger and Judith Meece, "Gender and Academic Motivation," International Encyclopedia of
Achievement can be a strong component in the role of gender women than eligible men. A distinction may be required the achievement based on skill and good quality (the main focus is female) and achievement based on the demands and competence of the aggressive (the main focus is men) where women are winning the success which is ductile, while the male is a competitor that is ductile.

Although women have a higher level of achievement, because of the social factors that demand women to be trustworthy, sensitive and come to think the welfare of others.

In contrary to the nature of feminism, the masculine that is characteristic of men, that is independent, active, competitive, easy to make a decision, likely to play a role as a leader, do not give up easily, self-confident, feel superior, ambitious and able to survive in the condition that gives you stress. This pushes men to have more feelings than women to do the deeds of anything to achieve their desires.

Overall, in general, women include student services, acquire ranking higher, and have the ability to read better than men. In a national study done recently, the women's show achievements in reading and writing skills better than males in grades $4,8,12$, where class. Compared to women, men are more often included in special/remedial. Compared to men, women tend to be more good at handling the material academically, giving

the Social \& Behavioral Sciences 2 (2015): 37, https://doi.org/10.1016/B978-0-08-097086-8.260819. 
attention to lessons in class, trying harder to complete academic tasks, and participating in study.

\section{EFL Classroom}

\section{a. The Nature of EFL Classroom}

The status of the English language in Indonesia is as English Foreign Language. Generally, in the EFL classroom, both teachers and students as non-native speakers have to communicate in English mostly for the whole teaching and learning process to help them acquire the target language. Meanwhile, English as a second language (ESL) and English as a foreign language (EFL) studies are conducted worldwide. ESL and EFL have many similarities but their many differences too. Both EFL and ESL have mission statements and value to guide them, intending to provide a good teaching-learning environment. ESL and EFL endorse professionalism in language education, and thus they can know that by teaching professionally, they can produce professional people. Both EFL and ESL's missions are to develop and maintain expertise in English, more so teaching and speaking English to speakers of another language worldwide.

As an international language, the English language can be EFL and ESL for the students who learn this language both for knowledge and for communication. The difference between both EFL and ESL. An EFL classroom there are in a country where English is not the domain language. Student shares the same language and culture. While ESL classrooms are in a country where English is the domain language use, the class is usually mixed nationalities, so students don't share a native language or common culture. Outside the classroom, students have a specific ability, practical need for English, and the opportunity to use it. Students have extensive daily programs to English-speaking culture, although their language skills may limit their understanding.

Many young people learn English as a secondary option as they learn it to facilities communication. English as Second Language (ESL) and English as a Foreign Language (EFL) require two different teaching strategies for several reasons. Most people don't know the difference between EFL and ESL and don't consider the difference when they depart to teach English. It's important to know what each one is so that the students' different needs can be met. For starters, an ESL classroom is far more likely to have students from various countries, all with different native languages, while an EFL classroom isn't. In this instance, the teacher needs to prepare for different cultures and linguistic errors along the way.

The EFL classroom will run well if the teacher ad the students have collaborative roles to make it real. The classroom of EFL students will usually all be from the same country. The students will have the same culture and make similar mistakes in the target language. Therefore, the teacher can rectify these mistakes as a whole rather than individually with the ESL learner. Besides, ESL students will also have different 
reasons for learning English. If they live in English-speaking countries, they will have a communicative need to learn English very quickly to go out to do their daily activity with ease.

\section{b. The Four EFL Learning Skills \\ 1) Listening}

Listening is the language skill that learners usually find the most difficult. This often happens because the students feel under unnecessary pressure to understand every word. To overcome matters related to the case, the teacher plays an important role that is defined in the following steps.

It is important to help students prepare for the listening task well before they hear the text itself. First of all, teachers must ensure that students understand the language they need to complete the job and are fully aware of their expectations. Make the students' convincing that they do not need to understand every word they hear.

The next important step is to encourage students to anticipate what they are going to hear. In daily activities, the situation, the speaker, and visual clues all help us to decode verbal messages. A way to make things a bit easier for the students is to present the listening activity within the context of a teaching unit's topic. Without realizing it, this will help students to predict what the answers might be. The teacher can help them further by asking questions and using the illustration to encourage them to guess the answers before they hear the text.
During listening, the students should be able to concentrate on understanding the message, so make sure they are not trying to read, draw, and write simultaneously. Always give a second chance to listen to the text to provide a new opportunity for those who could not do the task.

Finally, when students have completed the activity, invite answers from the whole class. Try not to put the individual student under proper pressure. Rather than confirming whether an answer is correct or not, you must give a variety of answers, in which case list them all on the board and play the text again so that the class can listen and choose the correct one.

\section{2) Speaking}

Many language students consider that developing speaking skills should be one of their primary goals because they would derive some personal satisfaction from it or feel it would be useful in pursuing other interests or career goals.

This emphasis on oral proficiency does not mean that other skills should be neglected. Since the ability to function adequately in speaking continues to be an important goal for many second language learners, it is incumbent upon us as language teachers to identify effective strategies for teaching oral skills in the classroom that will maximize opportunities for the development of useful levels of proficiency in speaking and listening as an integrated skill whole.

For any speaking activity to be successful, the students need to 
acknowledge that there is a real reason to ask a question or give a piece of information. Therefore, the teacher should make sure the students' activities provide a basis for speaking, whether something enjoyable or to find out real information about interesting items.

Once the activity begins, the teacher should make sure that they speak English as much as possible without interfering to correct the mistakes they will probably make. Try to treat the problem casually by praising the utterance and simply repeating it correctly without necessarily highlighting the problem. Finally, always offer praise for effort regardless of the accuracy of the English produced.

\section{3) Reading}

To make reading an exciting challenge instead of a tedious chore, students must not labor every word, whether they are skimming the text for general meaning or scanning it to pick out specific information. ${ }^{20}$ Other things to keep in mind are choosing texts, considering their difficulty level and their interest or humor so that children will want to read for the same reasons they read in their own language, to find out something they do not already know or new.

As with listening activities, it is important to spend time preparing for the task by using the illustrations (a usual feature in reading activities for children), students' own knowledge about the subject matter, and key vocabulary to help

${ }^{20}$ Michael Alexander Kirkwood Halliday and J. R. Martin, Readings in Systemic Linguistics (London: Batsford Academic and Educational, 1981). them predict the general content of the sentence. Discuss the subject and ask questions to elicit language and stimulate the students' interest in the text before reading. Also, make sure that the students understand the essential vocabulary they need to complete the task before reading.

While the children are reading the text, move around the class providing support if students need it. If possible, it helps and encourages students to find out the meaning of vocabulary as they come across it, using the context and the supporting illustrations.

Do not encourage students to read text aloud unless they learn a play or recite a poem. Reading aloud inhibits most students and forces them to concentrate on what they are saying instead of what they are reading, and the meaning is very often lost.

4) Writing

EFL students progress from writing isolated words and phrases to short paragraphs about themselves or very familiar topics such as family, home, hobbies, friends, food, etc.

Since many students are not yet capable, either linguistically or intellectually, of creating a piece of written text from scratch, time must be spent building up the language they need and provide a model on which they can then base their own efforts. The writing activities generally appear towards the end of a unit so that students have had plenty of exposure to the language and practice of the main structures and vocabulary they need. 
At this stage, the students' assignments will always contain mistakes. Again, the teacher should try to be more sensitive in their correction and not necessarily insist on every error being highlighted. A piece of written work covered in red pen is marked and generally counter-productive. Where possible, encourage students to correct their own mistakes as they work. If there is time, encourage students to decorate their written work and, where feasible, display their efforts in the classroom.

Therefore, the teacher needs to manage the classroom well because classrooms are among the most complex working environments in which professionals have to operate and engage learners in lesson activities.

\section{B. Method}

This research uses a descriptive qualitative method because the data is described using words or sentences to analyze gender student cheating behavior in the EFL Classroom. ${ }^{21}$ It is focused on the factors (inputs) leading to cheatingbehaviors by gender (process) and strategies used by the teacher (The result of descriptive qualitative does not show statistical procedures in analyzing the data, but the results present data in the form of description. ${ }^{22}$

21 Robert Bogdan and Sari Knopp Biklen, Qualitative Research for Education: An Introduction to Theory and Methods (Boston: Allyn and Bacon, 1998), 17.

22 John W. Creswell, Research Design: Qualitative, Quantitative, and Mixed Methods Approaches, 3rd ed. (California: SAGE Publications Ltd, 2009), 22.

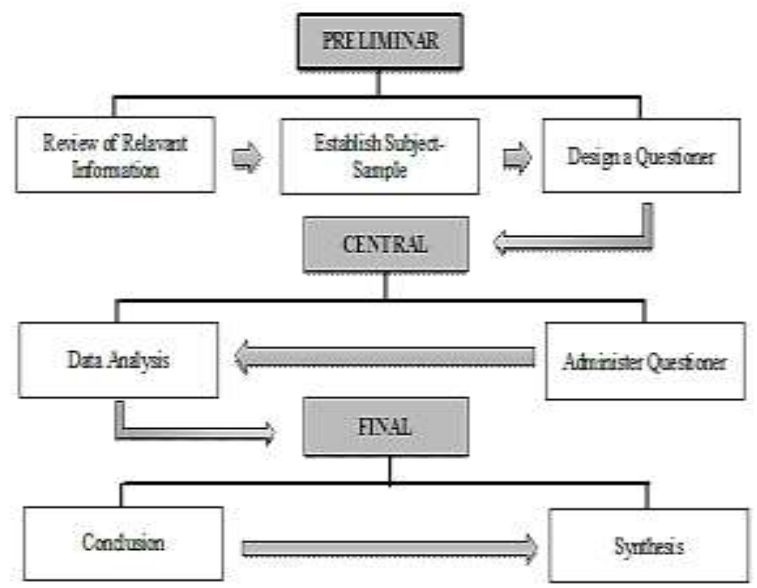

Fig. 1. Presenting the descriptive data in qualitative research

The population of this research was in the UPT SDN 1 Rijang Panua. In addition, the total population is 111 students in the academic year 2019/2020. There were six classes, 1st Grade to 6th Grade. In this research, the researcher assumed that such sample class had been selected and that the 4th to 6th Grade of 60 students had been chosen as a sample for this research, so that the total sample number was 60 .

The following techniques were used to collect data for this study: 1) Interview, and 2) Questionnaire. In the interview section, there are 10 questions that the English teacher would answer. The researcher asked the English teacher the strategies to overcome the cheating behavior of students in the classroom. The researcher focuses on strategies. The questionnaire functions to find out what influences the behavior of cheating students. Both instruments reinforce each other. The result of the questionnaire is conducted to investigate the genderbased cheating behavior of students. The researcher spreads the questionnaire to 
support the interview in order to know the factors that influence students' cheating behavior in the classroom.

Researchers have taken several steps in carrying out this study. Interview and questionnaire.

1. Interview: Researchers will request teachers' strategies in the English language to address "classroom cheating through voice, not WhatsApp.

2. Questionnaire: To detect factors that influence the "betrayed behavior of the class," researchers distributed questionnaires in support of interviews in three ways, sending files to the WhatsApp group, manual questionnaires, and google form.

It will be analyzed descriptively since the research design is descriptivequalitative. The researchers will be able to analyze the data in four steps. The first is collecting data after completing the data from preliminary research and field research. The second is transcribing the result of an interview with the English teacher concerning the teacher's strategies for overcoming student cheating behavior and influencing cheating behavior. Then the data were synthesized by research, and the technique and other associated data were indexed. The third is describing the results of the teachers' interviews. The researchers analyze the documents and the questionnaire based on the student's observation in the analysis. The researcher will obtain data on the factors why the students are cheating. And the last is to give meaning to the researcher and interpret the data. After analyzing all the data, the researcher will start describing the findings and explain all the data. The researcher's description was based on the data gathered in the literature review. In the specific yet brief and clear description, the researcher then analyzed the data.

\section{Results}

The final factors and strategies used depend significantly on such aspects as the case factor, the individual factors, the teachers, and a form of social actives, individualistic - opportunistic, individually planned, and socially passive.

These research findings show us that UPT SDN 1 Panua students from 4to 6-grade classes admit that they are cheating, and 100 percent of respondents admit that sometimes it is done in a certain way, in a certain situation, and under specific conditions.

\section{The Factor which Influences Students Cheating Behavior in EFL Classroom}

Three factors influence the behavior of the EFL students in the classroom: situation factors, individual factors, and teacher factors.

\section{a. Factor of Situation}

This category shows the research results as below of the ten factors listed as the cause of the students' cheating behavior. The lists can be seen in the following figure below. 


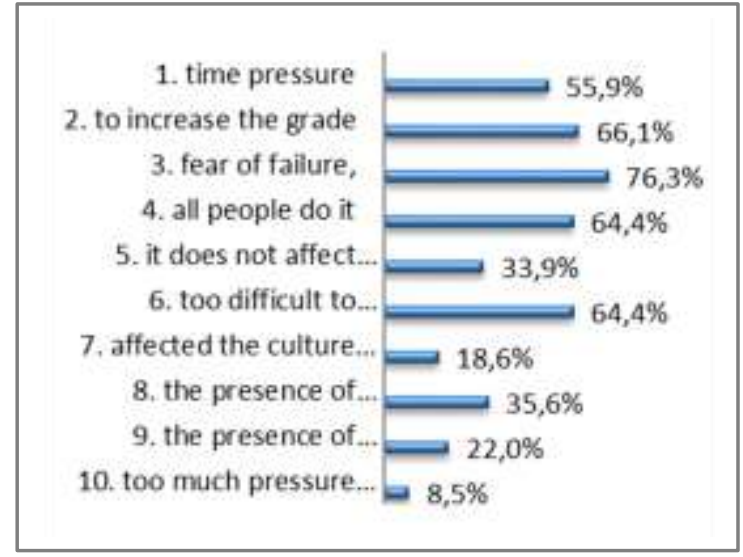

Fig. 2. Students' Cheating Behavior by Situational Factor

There are 33 students, or up to 55.9 percent of those who choose that reason, first time pressure. Secondly, to increase the level, $39(66.1 \%)$ of students selected this reason for this survey. Third, Fear of failure, the reason that is most chosen by students with around 45 students or up to $76,3 \%$, is Fear of failure in this situation. Fourth, all students are doing that. This is the reason 38 students or $64.4 \%$ of students choose. Fifth, because it does not affect everyone else, students who choose to do so think it has no bearing on each other, about 20 (33.9\%). The results of a survey show, sixthly, that around 38 students, or 64.4 percent of the total number of students, chose those reasons these are too difficult to answer.

This survey's findings show that 11 students $(18,6 \%)$ chose the reason because they know this Seventh, Impacted instant culture Eighth, Less stringent monitoring, This is why 21 students or 35,6 percent of students have chosen to attend. Ninth, if not completed, severe fines show 13 students or as many as 22 percent of students.

\section{b. Individual Factors}

Eight factors in this category influence student misappropriation. Based on the results of the 60 students UPT SDN 1 Chert Panua survey questionnaire, data show that the following products are cheating.

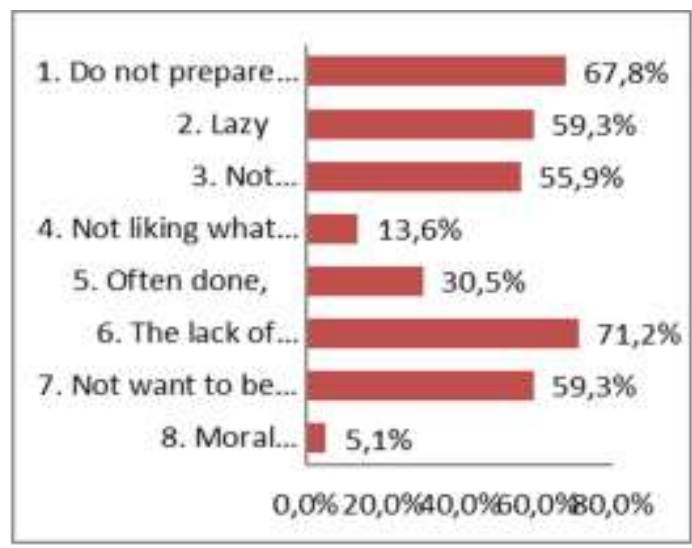

Fig. 3. Students' Cheating Behavior by Individual Factor

Because of the finding of individual factors, some students have not been well prepared to study well, proving they are very lazy. Do not understand what has been learned or do not like what they do is because teachers often ask what students understand or don't take shame in admitting that their ignorance prefers to understand. Of course, cheating is a behavior most often performed, lack of confidence in their ability. As McTernan, Love, and Rettinger state that cheats is caused by a lack of self-control. ${ }^{23}$ They do not want to be treated like a disloyal man, and the moral education of a good less applied by students.

\footnotetext{
23 Melissa McTernan, Patrick Love, and David Rettinger, "The Influence of Personality on the Decision to Cheat," Ethics \& Behavior 24, no. 1 (2014):

53-72,

https://doi.org/10.1080/10508422.2013.819783.
} 


\section{c. Teacher Factor}

Teacher factors also contribute to why the students cheat. Here are the cheating behaviors influenced by the teacher factor.

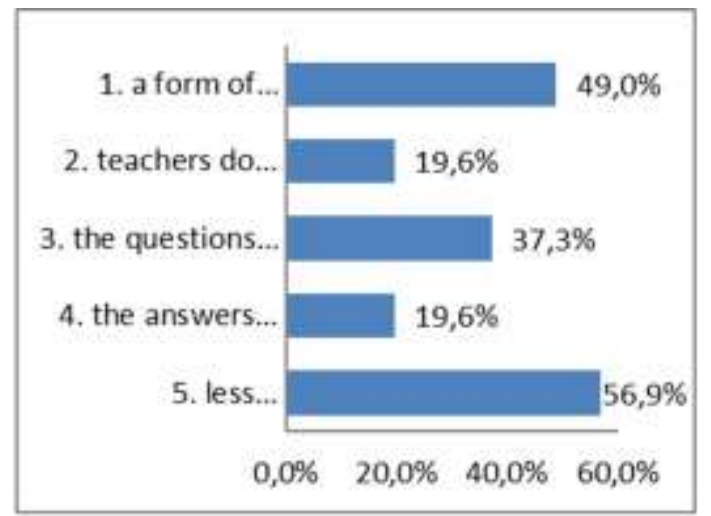

Fig. 4. Students' Cheating Behavior by Teacher Factor

The factors that teachers contribute to student cheating also determine that student cheating is not fair or determines the class level by researchers who know that they do not believe that the teacher is fair. Teachers sometimes do not prepare their learning well in the learning process, so lessons are taught to make the students bored and less careful about what the teacher presents themselves. Poor teaching makes the students less interested in the course and materials. It is one of the factors why the students cheat. $^{24}$

Cheating is also caused by answers that always questioned Deuteronomy on the death of the memorial books, and teachers provide the students with less

\footnotetext{
${ }^{24}$ Diana Starovoytova and Saul Namango, "Factors Affecting Cheating-Behavior at UndergraduateEngineering," Journal of Education and Practice 7, no. $\quad 31 \quad$ (2016): 66-82, https://files.eric.ed.gov/fulltext/EJ1122521.pdf.
}

understanding that they need the value of the study, but to what extent they have understood the results. Apart from the above factors, we can also know that students are commonly involved in some form of cheating including 1) social activity is seeing and asking a replay friend, good friends, deskmate and other friends for an answer, 2) Individualistic-opportunistic, managed to use the mobile telephone because a teacher was neglected, reiterated that mobile telephone was not brought to school and the results showed that the students prepared themselves to notice and copied their work results, 3) Individually Planned, this is done individually with attention to the teacher's activities, both if the teacher leaves the classroom and when the teacher is picked up and replaced by opening a textbook., and 4) Social Passive, they did not hesitate in answering their friends' difficulties and sharing the answers there to the students, who do not want to be considered disloyal, allow their friend to see and copy their evaluation.

\section{Teachers' Strategies which are Used to Overcome Students' Cheating Behavior in the EFL Classroom}

The results from the interview, the conclusions that can be cited from the third speaker/leader, allow researchers to draw a range of ways to address cheating students' habit.

\section{a. Explain the harmful effects of cheating}

Teachers play a major role in how they explain and understand the students involved. A teacher is called to do this 
when dealing with students' problems or disease (the custom of cheating).

\section{b. Include early age character education}

Since the official force of the Curriculum 2013 (K13) has replaced KTSP 2006 since 2016, character education is more important than academic value, which is 60 percent as seen by the attitudinal and spiritual values. This is why students are trained and guided towards the character. One of them is honest behavior.

\section{c. Provide question report or quiz exercises}

It trains the students' reflective memory by giving many practices answering questions during the learning process.

\section{d. Give praise or appreciation}

By praising, although only the values of standards are obtained, students are encouraged to learn more and increase their achievements. If students are less able to study, it certainly doesn't mean that they don't feel attractive to other students because they are no stupid students because they can still be at a teaser. Nobody can catch up fast. Others need longer to get a sense.

\section{The Difference in Student Attitudes}

\section{Towards Cheating Behavior by Gender}

There is no gender-based difference between a student's cheating behavior, with the student population of men and women equal to 30 male and 30 female students. However, if you can understand that there are male students in the field, they are more active than female students.

\section{Conclusion}

The influencing factor for EFL Classroom students is the first category is a situational factor, the second category is the individual, and the third category is the teacher factor. Theory Besides these factors, we can also know that students often use some cheat, such as socially active, individualistic, individually planed, and socially passive. Teacher strategies that are used in the EFL classroom to overcome student cheating. The researcher concludes that in the EFL classroom, there are four strategies in place to overcome student cheating behavior, they are: 1) explaining the negative effect of cheating behavior, 2) instilling early character education, 3) giving exercises in the form of questions or quizzes, and 4) giving appreciation or praise. The difference in student behavior in the direction of gender cheating. Researchers have found that the student population of men and women is the same as 30 male students and 30 female students, but their gender-based behavior is not different.

\section{References}

Agger, Charlotte, and Judith Meece. "Gender and Academic Motivation." International Encyclopedia of the Social \& Behavioral Sciences 2 (2015): 37. https://doi.org/10.1016/B978-0-08097086-8.26081-9. 
Altmann, Tanya K. "Attitude: A Concept Analysis." Nursing Forum 43, no. 3 (2008): 144-50. https://doi.org/10.1111/j.17446198.2008.00106.x.

Anderman, Eric M., and Tamera B. Murdock. Psychology of Academic Cheating. Amsterdam: Elsevier, 2011.

Athanasou, James, and Olabisi Olasehinde. "Male and Female Differences in Self-Report Cheating." Practical Assessment, Research, and Evaluation 8, no. 1 (2019): $1-12$. https://doi.org/10.7275/b4te-5z13.

Blankson, Samuel. Attitude. North Carolina: Lulu.com, 2005.

Bogdan, Robert, and Sari Knopp Biklen. Qualitative Research for Education: An Introduction to Theory and Methods. Boston: Allyn and Bacon, 1998.

Cots, Josep-Maria. "Teaching 'with an Attitude': Critical Discourse Analysis in EFL Teaching." ELT Journal 60, no. 4 (2006): 336-45. https://doi.org/10.1093/elt/ccl024.

Creswell, John W. Research Design: Qualitative, Quantitative, and Mixed Methods Approaches. 3rd ed. California: SAGE Publications Ltd, 2009.

Dewey, John. Experience And Education. New York: Simon and Schuster, 2007.

Diego, Leo Andrew B. "Friends with Benefits: Causes and Effects of Learners' Cheating Practices During Examination." IAFOR Journal of Education 5, no. 2 (2017): 121-38. https://doi.org/10.22492/ije.5.2.06.

Halliday, Michael Alexander Kirkwood, and J. R. Martin. Readings in Systemic Linguistics. London: Batsford Academic and Educational, 1981
Hetherington, E. Mavis, and Solomon E. Feldman. "College Cheating as a Function of Subject and Situational Variables." Journal of Educational Psychology 55, no. 4 (1964): 21218.

https://doi.org/10.1037/h0045337.

Kukolja Taradi, Suncana, Milan Taradi, and Zoran Dogas. "Croatian Medical Students See Academic Dishonesty as An Acceptable Behaviour: A Cross-Sectional Multicampus Study." Journal of Medical Ethics 38, no. 6 (2012): 376-79. https://doi.org/10.1136/medethics2011-100015.

Lazar, M., ed. Feminist Critical Discourse Analysis: Gender, Power and Ideology in Discourse. London: Palgrave Macmillan, 2005. https://doi.org/10.1057/978023059 9901.

Lidestav, Gun, and Annika Egan Sjölander. "Gender and Forestry: A Critical Discourse Analysis of Forestry Professions in Sweden." Scandinavian Journal of Forest Research 22, no. 4 (2007): 35162.

https://doi.org/10.1080/028275807 01504928.

Maio, Greg, and Geoffrey Haddock. The Psychology of Attitudes and Attitude Change. California: SAGE Publications, 2009.

McTernan, Melissa, Patrick Love, and David Rettinger. "The Influence of Personality on the Decision to Cheat." Ethics \& Behavior 24, no. 1 (2014): 53-72. https://doi.org/10.1080/10508422.2 013.819783.

Pratkanis, Anthony R., Steven J. Breckler, and Anthony G. Greenwald. Attitude Structure and Function. East Sussex: Psychology Press, 2014. 
Samani, Muchlas, and Hariyanto. Pendidikan Karakter Konsep dan Model. PT Remaja Rosdakarya, 2013.

Saptono. Dimensi-Dimensi Pendidikan Karakter: Wawasan, Strategi, dan Langkah Praktis. Jakarta: Erlangga, 2011.

Sheard, Judy, Selby Markham, and Martin Dick. "Investigating Differences in Cheating Behaviours of IT Undergraduate and Graduate Students: The Maturity and Motivation Factors." Higher Education Research \& Development 22 (2003): 91-108. https://doi.org/10.1080/072943603 2000056526.

Starovoytova, Diana, and Saul Namango. "Factors Affecting CheatingBehavior at UndergraduateEngineering." Journal of Education and Practice 7, no. 31 (2016): 6682.

https://files.eric.ed.gov/fulltext/EJ1 122521.pdf.

Syarif, Zainuddin, and Abdul Gaffar. "The Model of National Character Education in Darul Ulum Islamic Boarding School of Banyuanyar, Pamekasan Madura." In Proceedings of the International Conference on Islamic Education (ICIE 2018), 261:119-22. Bandung, Indonesia: Atlantis Press, 2018. https://doi.org/10.2991/icie18.2018.22. 